\title{
AGE, REPRODUCTION, AND FECUNDITY OF A POPULATION OF COBITIS SP. (ACTINOPTERYGII: CYPRINIFORMES: COBITIDAE) FROM THE BABOLRUD RIVER IN THE SOUTHERN CASPIAN SEA BASIN
}

\author{
Hamed MOUSAVI SABET ${ }^{1 *}$, Abolghasem KAMALI $^{2}$, Mehdi SOLTANI $^{3}$, Ali BANI ${ }^{4}$, \\ Hamid Reza ESMAEILI ${ }^{5}$, Hosseinali ROSTAMI ${ }^{6}$, Saber VATANDOUST ${ }^{7}$, \\ and Zeynab MORADKHANI ${ }^{2}$ \\ ${ }^{1}$ Young Researchers Club, Science and Research Branch, Islamic Azad University, Tehran, Iran \\ ${ }^{2}$ Department of Fisheries, Science and Research Branch, Islamic Azad University, Tehran, Iran \\ ${ }^{3}$ Department of Fish Health and Diseases, Faculty of Veterinary, University of Tehran, Iran \\ ${ }^{4}$ Department of Fisheries, Faculty of Natural Resources, University of Guilan, Iran \\ ${ }^{5}$ Department of Biology, College of Sciences, Shiraz University, Iran \\ ${ }^{6}$ Iranian Fisheries Research Institute, Golestan, Iran \\ ${ }^{7}$ Department of Fisheries, Babol Branch, Islamic Azad University, Babol, Iran
}

Mousavi Sabet H., Kamali A., Soltani M., Bani A., Esmaeili H.R., Rostami H., Vatandoust S., Moradkhani Z. 2011. Age, reproduction, and fecundity of a population of Cobitis sp. (Actinopterygii: Cypriniformes: Cobitidae) from the Babolrud River in the southern Caspian Sea basin. Acta Ichthyol. Piscat. 41 (2): $117-122$.

\begin{abstract}
Background. Loach fishes, Cobitis sp., are found in the majority of streams in the southern Caspian Sea basin, but reproductive parameters of them are barely known. Reproductive conditions are key parameters of fish populations and their assessment is very important for several reasons. Therefore, the main aim of this study was to obtain reproductive characteristics of this fish which will be a first report for the basin.

Materials and methods. Sampling was done at monthly intervals throughout the year and 226 individuals of Cobitis sp., were caught from the Babolrud River in the southern Caspian Sea basin, north of Iran. Age, sex ratio, fecundity, oocytes diameter, gonadosomatic- and modified gonadosomatic indices were estimated. Regression analyses were used to find relations between fecundity and fish size (length and weight), gonad weight, and age. Results. Sex ratio differed significantly from unity, and the percentage of females was greater than that of males. The mature females and males were longer than 45 and $35 \mathrm{~mm}$ in total length $(+2$ and +1 in age, respectively). The average egg diameter was $0.58 \mathrm{~mm}$. The spawning took place from beginning of May to late July, when water temperature was between 19.1 and $24.6^{\circ} \mathrm{C}$. Average GSI value at the beginning of the reproduction period was $8.93 \%$ and ranged between $4 \%$ and $26 \%$ in ripe, mature females. The average of absolute and relative fecundity was calculated 2172 and 590, respectively. The absolute fecundity was significantly related to body weight and gonad weight.

Conclusion. Based on the pattern of gonadosomatic index, it was concluded that this fish has a prolonged active reproductive period. Their reproduction in this basin shows some differences from other reports, which might be related to different environmental conditions.
\end{abstract}

Keywords: gonadosomatic index, oocyte diameter, ovary, spawning, loach

\section{INTRODUCTION}

The cobitid fishes are represented in Iran by Cobitis linea (Heckel, 1847) and another not clearly identified species, occurring south of the Caspian Sea basin. Some authors reported the latter fish as Cobitis taenia Linnaeeus, 1758 (see Coad 2008, Abdolī and Nāderī 2009) whereas some other researchers disagreed owing the fact that Cobitis taenia is rather a north-European species and its occurrence in the southern Caspian Sea basin would be unlikely (Kottelat and Freyhof 2007). It is possible that the cobitid fish occurring at latter location might represent a new species. Therefore, for the purpose of this paper, the south Caspian loach in question will be referred to as Cobitis sp.

The earlier mentioned Cobitis linea can be found in the Kor River basin and the upper Kul River drainage of the Hormozgan basin (Banarescu and Nalbant 1966, Bianco and Nalbant 1980). Southern Caspian Sea loach

\footnotetext{
${ }^{*}$ Correspondence: Hamed Mousavi Sabet, PhD in Fish Biology, Young Researchers Club, Sciences and Research Branch, Islamic Azad University, P.O. Box: 14155-4933, Tehran, Iran, phone/fax: +982144129257, e-mail: Mosavii.h@gmail.com
} 
(Cobitis sp.) is an endemic fish from south of the Caspian Sea basin in north of Iran. This fish is distributed in the lower stretches of rivers along the basin (Abdoli and Nāderī 2009). Members of this family (Cobitidae) are small, benthic, freshwater fishes with a wide distribution area covering large parts of Eurasia and Africa (Perdices and Doadrio 1997). Those fishes remain buried in sand, mud, or dense weed growths during the day, being active at night and they exhibit mostly solitary behaviour (Coad 2008). The loaches achieve sexual maturity in the first- (males) or second (females) year of their life (Marconato and Rasotto 1989, Boroń and Pimpicka 2000).

The principal aim of this paper was to provide data on the reproductive biology of the fish, including sex ratio, gonadosomatic index, fecundity, oocyte diameter, and spawning season time and duration which are necessary for conservation programs of this fish. We believe that information on the reproductive biology of this small and colourful loach may be important in view of its potential aquarium trade.

\section{MATERIALS AND METHODS}

Study area, sampling, and habitat. The study was conducted in the Babolrud River (lat $36^{\circ} 26^{\prime} \mathrm{N}$, long $52^{\circ} 35^{\prime} \mathrm{E}$ ) in south of the Caspian Sea basin, north of Iran. Fish were collected from this river monthly from May 2009 to April 2010 by electrofishing (200-300 V). The water temperature of the sample site was measured simultaneously. This fish, Cobitis sp., is commonly found in tributary streams of the Babolrud River. The bottom of these water bodies is generally sandy with occasional silt and pebbles (5-30 cm in diameter), and the water is clear and slow running. The analysis of water at two different stations in May showed that the temperature was $19.1-20.2^{\circ} \mathrm{C}$; $\mathrm{pH} 6.9-7.0, \mathrm{O}_{2} 5-9 \mathrm{mg} \cdot \mathrm{L}^{-1}$, and the water hardness $224 \mathrm{mg} \cdot \mathrm{L}^{-1}$.

Biometry and data analysis. The fish were measured (total length $=\mathrm{TL}$; standard length $=\mathrm{SL}$ ) to the nearest $0.1 \mathrm{~mm}$ and weighed (body weight $=W_{b}$ ), to the nearest $0.01 \mathrm{~g}$. The gonads were weighed (gonad weight $=W_{g}$ ) to the nearest $0.001 \mathrm{~g}$. To examine the monthly changes in gonads as a mean for estimating the spawning season of this loach: gonadosomatic index (GSI) and modified gonadosomatic index (MGSI) were calculated following the formulas: $\mathrm{GSI}=\left(W_{g} \times W_{b}^{-1}\right) \times 100$ and MGSI $=\left(W_{g} \times\right.$ $\left.W_{b}^{-1}\right)-W_{g} \times 100$ (Nikolsky 1963).

Altogether, the absolute fecundity $\left(F_{a}\right)$ was estimated in 30 ovaries by calculating the number of oocytes with a diameter greater than $0.2 \mathrm{~mm}$ (Kostrzewa et al. 2003). To achieve accurate results: fish that were caught in the beginning of May and June 2009 and in 6 May 2010 (before spawning), were used. The relative fecundity $\left(F_{r}\right)$ was expressed as the absolute fecundity $\left(F_{a}\right)$ dividing by the fish body weight. The result was the number of eggs per $1 \mathrm{~g}$ of body weight (Bagenal 1967). To determine the oocyte diameter, the ovaries were preserved in $10 \%$ formalin solution. The diameters of 60 ova of each female fish were measured using a Zeiss SV 6 disecting microscope outfitted with an ocular micrometer. The sex was determined based on the presence or absence of the Canestrini scale (lamina cribrosa i.e., a platelike ossificated extension of the ray - a secondary sexual character of males; Canestrini 1871) and the examinations of gonad morphology after dissection. The Chi square test was used to assess sex ratio deviation from a $50: 50$ (Wootton 1998). The fish were ageing according to scales taken from the left side of the body, between end of the pectoral fin and the beginning of the dorsal fin. In order to compare significant differences in the GSI index between samples taken on various months and various size samples, the analysis of variance (ANOVA I) was applied. The relation between the absolute fecundity $\left(F_{a}\right)$ and body length and weight, the gonad weight and the age of females was determined by regression analysis. The data were analyzed with the SPSS version 10.0 software and Microsoft Excel 2007 spreadsheet.

\section{RESULTS}

Size, sex ratio, and age. During this study, 226 specimens of Cobitis sp. were caught, ranging in total length from 31.1 to $92.5 \mathrm{~mm}$, standard length from 26.7 to 83.2 $\mathrm{mm}$, and total weight from 0.4 to $6.2 \mathrm{~g}$. The females were longer, heavier, and achieved maturity later (at the age of $2+$ ) than the males. Their TL exceeded $45 \mathrm{~mm}$ and the body weight approximated $2 \mathrm{~g}$. This population of loach had a narrow age range (1+ to $5+$ years). The majority of the fish caught were $2+$ and $3+$ years old, some were $1+$

Table 1

Length and weight (mean \pm SD) in different age groups of males and females of Cobitis sp. from the Babolrud River

\begin{tabular}{|c|c|c|c|c|c|c|c|c|}
\hline \multirow{2}{*}{ Age } & \multicolumn{2}{|c|}{$n$} & \multicolumn{2}{|c|}{$\mathrm{SL}[\mathrm{mm}]$} & \multicolumn{2}{|c|}{$\mathrm{TL}[\mathrm{mm}]$} & \multicolumn{2}{|c|}{$W_{b}[\mathrm{~g}]$} \\
\hline & M & $\mathrm{F}$ & M & $\mathrm{F}$ & M & $\mathrm{F}$ & $\mathrm{M}$ & $\mathrm{F}$ \\
\hline $1+$ & 10 & 15 & $28.93 \pm 1.86$ & $29.24 \pm 3.46$ & $33.25 \pm 2.18$ & $33.07 \pm 4.25$ & $0.41 \pm 0.08$ & $0.42 \pm 0.15$ \\
\hline $2+$ & 51 & 41 & $41.17 \pm 4.12$ & $37.69 \pm 5.08$ & $47.76 \pm 4.95$ & $46.19 \pm 5.74$ & $1.21 \pm 0.39$ & $1.55 \pm 0.29$ \\
\hline $3+$ & 36 & 43 & $48.35 \pm 1.74$ & $48.96 \pm 3.69$ & $56.28 \pm 2.49$ & $55.81 \pm 4.55$ & $1.72 \pm 0.19$ & $2.34 \pm 0.51$ \\
\hline $4+$ & 0 & 26 & - & $65.83 \pm 3.94$ & - & $75.23 \pm 4.72$ & - & $3.59 \pm 0.78$ \\
\hline $5+$ & 0 & 4 & - & $75.91 \pm 1.08$ & - & $87.34 \pm 2.11$ & - & $5.11 \pm 0.33$ \\
\hline
\end{tabular}

$\mathrm{SL}=$ standard length; $\mathrm{TL}=$ total length; $W_{b}=$ body weight; $n=$ number of specimens; $\mathrm{SD}=$ standard deviation; $\mathrm{M}=$ male; $\mathrm{F}=$ female. 
and $4+$ and only a few of them were $5+$ years old. The oldest females $(1.77 \%)$ among specimens were +5 years old but most of them $(40.71 \%)$ were in third year $(+2)$ of their lives (Table 1). The body length increased proportionally to the age. The older loaches were longer than those which had just reached sexual maturity (in the second and third year of life). The body weight of the older fish was heavier than the young ones. Of the total number of 226 fish specimens caught, 129 were females and 97 were males, giving an overall sex ratio of $1: 1.33$ and the difference between the number of females and males was significant $\left(\chi^{2}=4.5310 ; P<0.05\right)$.

Gonadosomatic and modified gonadosomatic indices. Significant differences were observed in female and male GSI and MGSI in different months $(P<0.05)$. There were no significant differences between GSI and MGSI $(P>0.05)$. The female indices increased during November to May, peaking at the mid of spring and then decreased until August, then showed a slow increase in October and finally decreased in November (Figs. 1, 2).

Oocyte diameter and fecundity. The oocyte diameter ranged from 0.02 to $1.4 \mathrm{~mm}$ with a mean of 0.5839 $\mathrm{mm}(\mathrm{SD} \pm 0.1578)$. They were highest in May and lowest in December. There was a peak in the number of yellowish-yolk oocytes (0.8-1.4 mm diameter) in May (Fig. 3).

The fish used to estimate fecundity were $3+, 4+$, or $5+$ years old. Individual values of the absolute fecundity varied in a wide range from 734 to 3562 eggs with an average of 2172.5

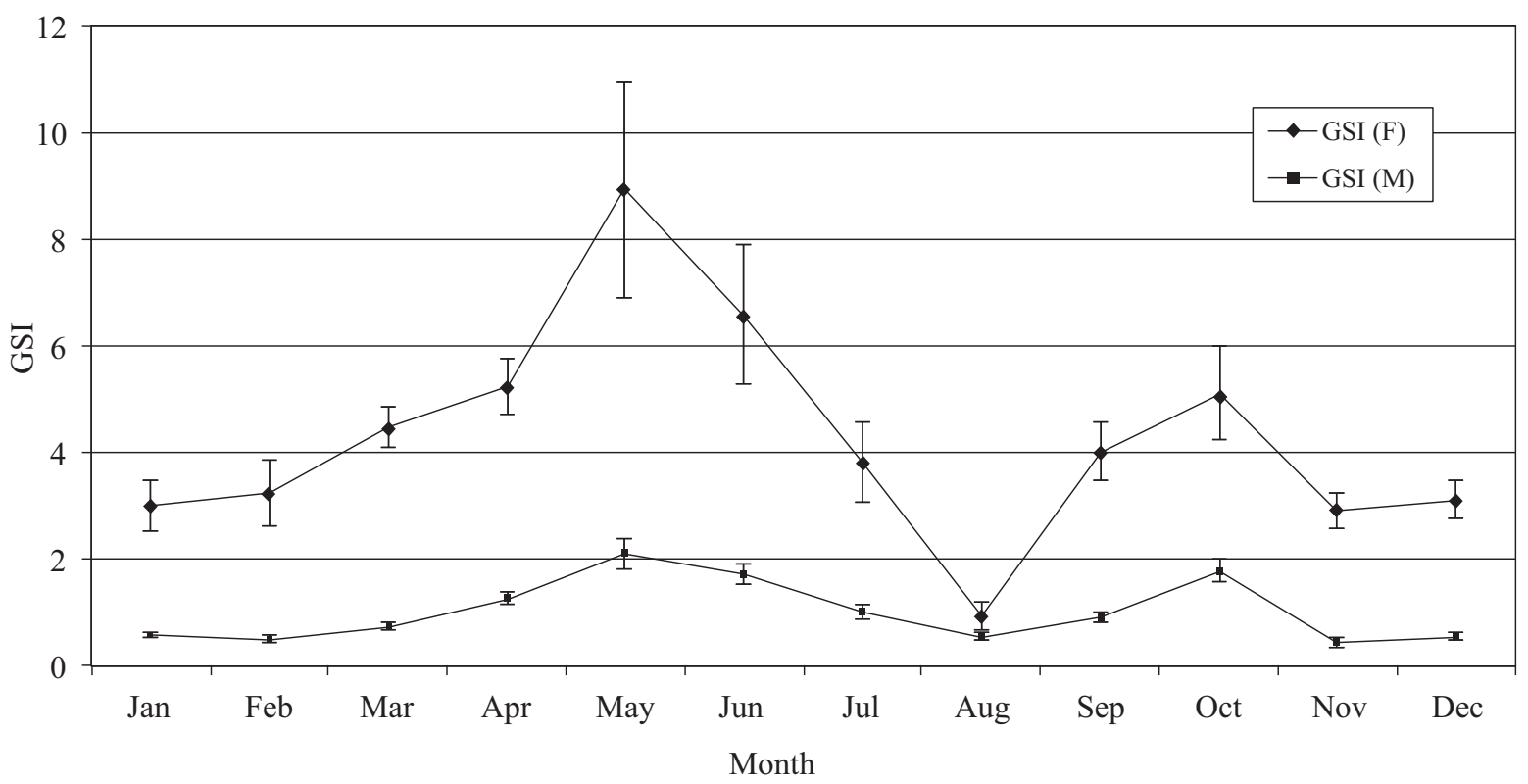

Fig. 1. Variation of mean $( \pm \mathrm{SE})$ gonadosomatic index (GSI) of female (F) and male (M) for Cobitis sp. from the Babolrud River in different months

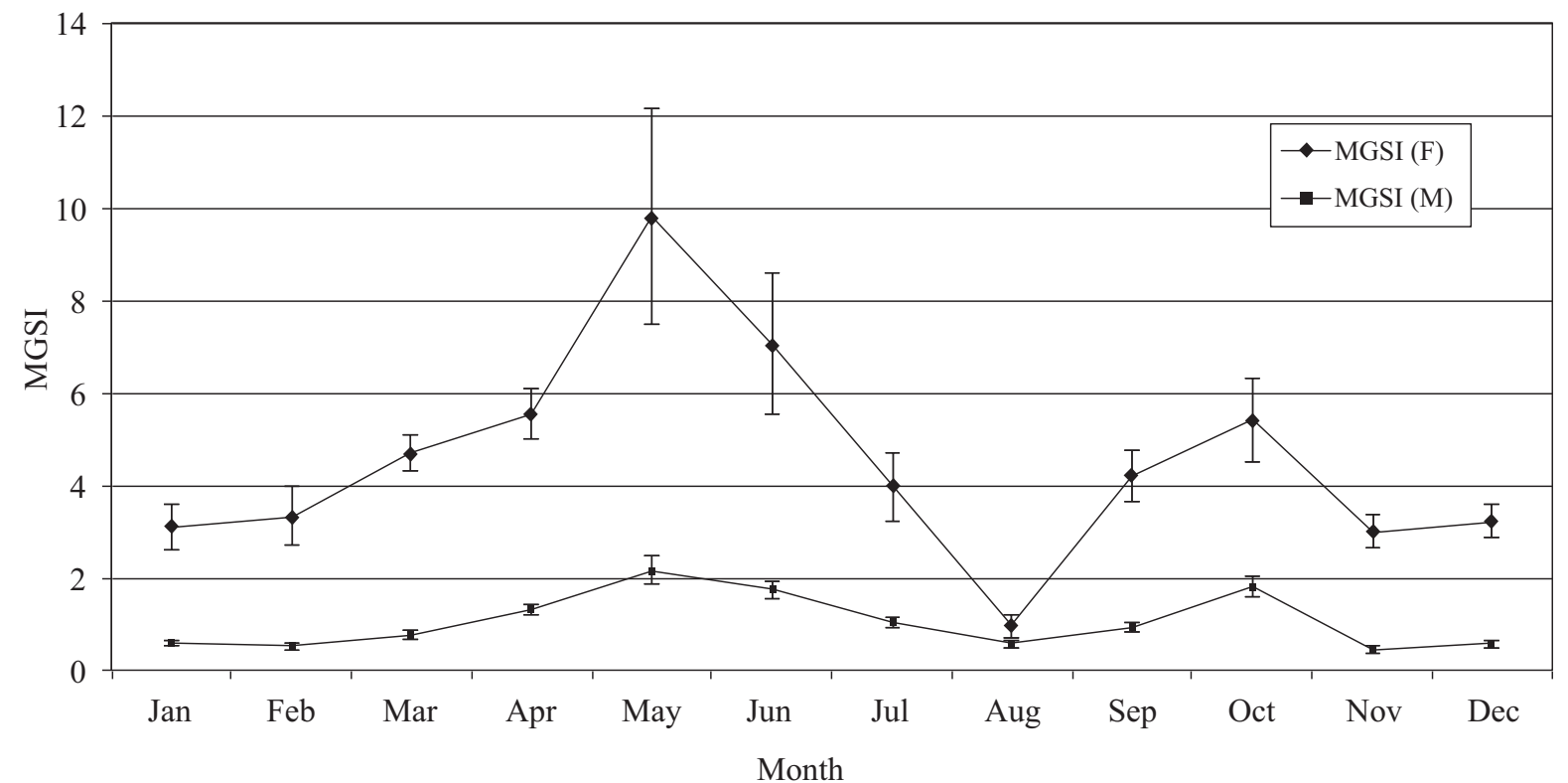

Fig. 2. Variation of mean $( \pm \mathrm{SE})$ modified gonadosomatic index (MGSI) of female (F) and male (M) for Cobitis sp. from the Babolrud River in different months 
$(\mathrm{SD} \pm 719)$. The relative fecundity was 347 to 945 with a mean of $590.08(\mathrm{SD} \pm 207)$ per gram body weight (Table 2$)$.

It was observed that the absolute fecundity accompanied the growth of weight of the female loaches. The absolute fecundity was significantly related to fish female body weight and also gonad weight (Table 3 ).

\section{DISCUSSION}

Age and size of fish. Females achieve maturity later than the males; at the age of 2+, SL is about $56 \mathrm{~mm}$ and body weight about 2 g (Robotham 1981, Boroń and Pimpicka 2000). The loach is a short-lived species, most of the caught fish were $2+$ and $3+$ years old, some were $1+$ and $4+$ and only a few of them were $5+$ years old (Robotham 1981), while in present study the oldest females $(1.77 \%)$ were $5+$ years old but most of them $(40.71 \%)$ were in the third year of their lives.

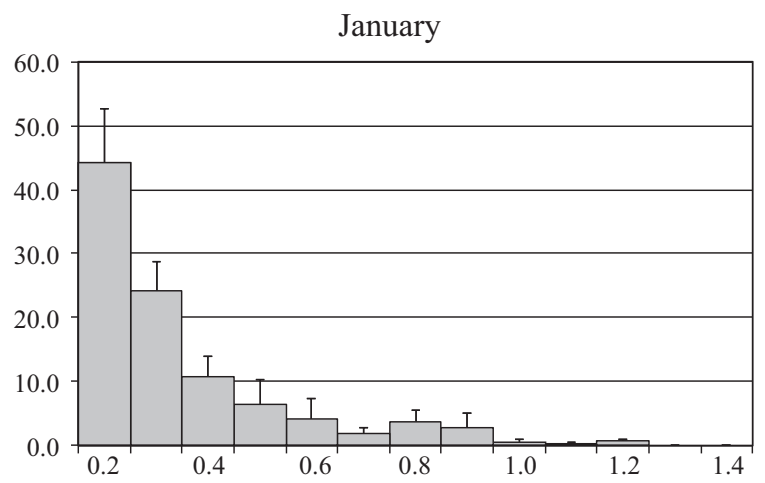

April

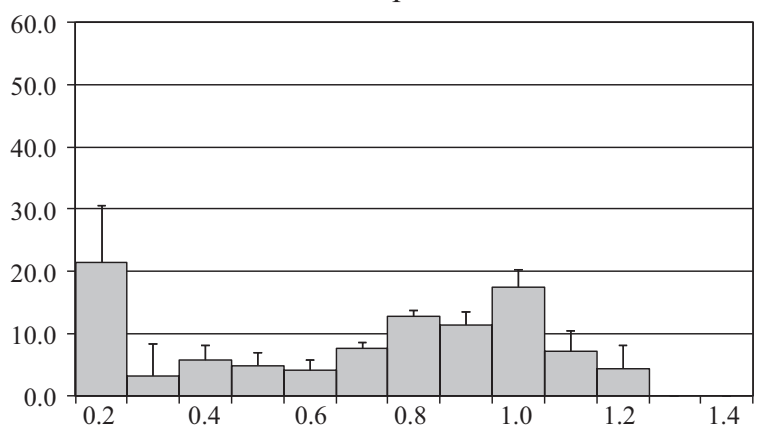

May

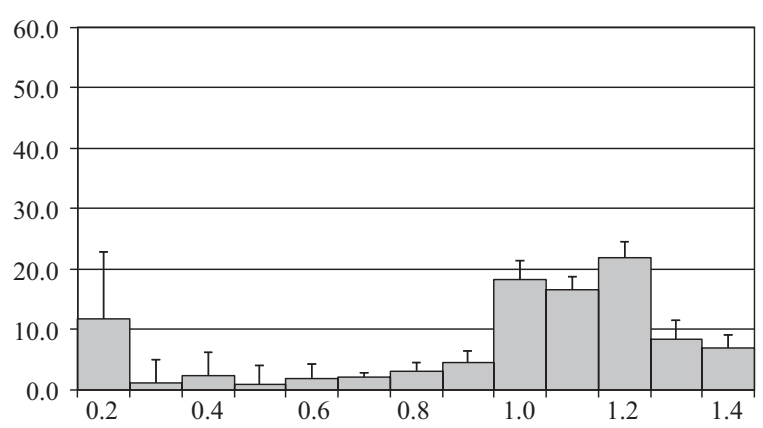

Reproduction. This is the first study concerning reproduction process of Cobitis sp. in southern part of the Caspian Sea basin. Spawning of C. taenia takes place from May to July, usually in shallow littoral, among the submerged vegetation where the water temperature is at least 16-18 ${ }^{\circ} \mathrm{C}$ (Boroń and Danilkiewicz 2000, Boroń and Pimpicka 2000). A similar time of spawning was observed for C. bilineata Canestrini, 1865 from northern Italy (Marconato and Rasotto 1989). A later spawning period (June-July) was observed for C. taenia from the United Kingdom (Robotham 1981). Ekmekçi and Erk'akan (2003) showed that the $C$. simplicispina Hankó, 1925 from Turkey begins to spawn in April, when the water temperature is $15^{\circ}$ and finishes in May. The spawning period in the Babolrud River lasted until the middle of July. As late as in mid-July, in some females ovaries filled with oocytes were observed ready to be laid. However, in August, the ovaries of all the

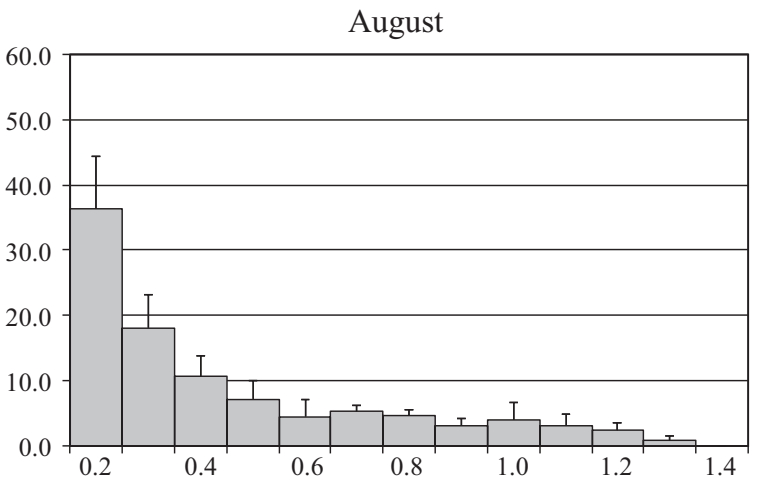

August

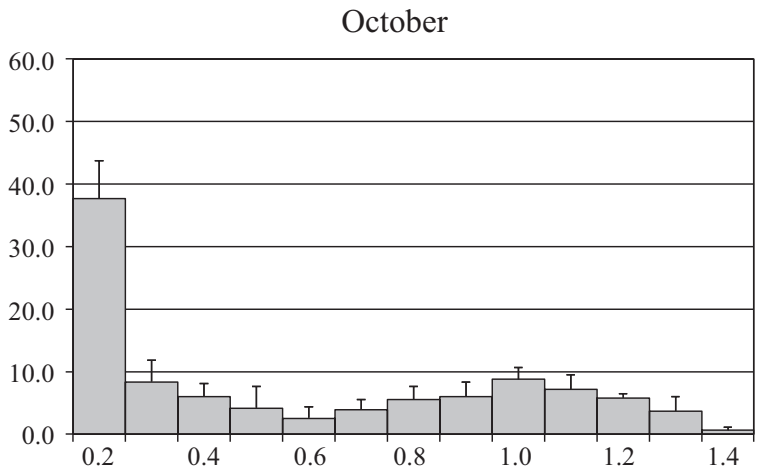

Fig. 3. The mean oocyte diameter $[\mathrm{mm}]$ in the gonads of Cobitis sp. from the Babolrud River 
loaches under study indicated end of the reproductive period. Then a secondary increasing in ovaries development was observed from August to October, when some of the fish was ready to spawn. In the Zegrzyński Reservoir, ovaries of the female loach were filled with mature eggs in August (Boroń and Pimpicka 2000).

The process of accumulating reserve substances in the ovaries of the females can be obtained partly by tracing the changes in the gonadosomatic index. In species which spawn in late spring and in summer such as loach, the index remains low in winter and then rises sharply just before the spawn (Wootton 1979, Marconato and Rasotto 1989, Rinchard and Kestemont 1996). A rapid increase in the weight of ovaries takes place when the temperature rises and increasing amounts of food are consumed (Wootton 1979). Changes in the gonadosomatic index, calculated for the population in which females spawn in batches, must not be used as the only credible indicator of the number of batches laid. The highest GSI values from $18 \%$ for the fish from Lucień Lake (Kostrzewa et al. 2003) to 26\% in the loach from Italy (Marconato and Rasotto 1989) were observed during the reproduction period. Values of GSI, reported by different authors varied widely:

- from $2 \%$ to $20 \%$ for C. elongatoides Bacescu et Maier, 1969 from the Czech Republic (Halačka et al. 2000);

- from $12 \%$ to $26 \%$ for C. taenia from Italy (Marconato and Rasotto 1989);

- from $7 \%$ to $17 \%$ for C. simplicispina Hankó, 1925 from Turkey (Ekmekçi and Erk'akan 2003);
- from $5 \%$ to $18 \%$ for Cobitis sp. from Lucień Lake (Kostrzewa et al. 2003);

- from $5.2 \%$ to $12.2 \%$ for C. elongatoides from Hungary (Erös 2000).

On the other hand, the highest average value of GSI (calculated in late April, before spawning), of the population of Cobitis sp. from the Babolrud River, was about $9 \%$, ranging from $4 \%$ to $26 \%$.

Fecundity. It is difficult to determine the fecundity in females which spawn in batches as the fish under study. In order to estimate the absolute fecundity of the loach from the Babolrud River, all the oocytes of at least $0.2 \mathrm{~mm}$ in diameter were counted. A similar limiting value was adopted for Cobitis sp. from Lucień Lake (Kostrzewa et al. 2003). Some authors included larger oocytes, over 0.3 mm (Boroń and Pimpicka 2000) or over $1 \mathrm{~mm}$ (Boroń and Danilkiewicz 2000). In this study, the average absolute fecundity of female loach from the Babolrud River was about 2172 eggs, ranging from 734 to 3562 eggs and the absolute fecundity of Cobitis sp. caught in Lucien Lake and Klawój Lake (Kostrzewa et al. 2003, Juchno and Boron 2006) were comparable to the estimated value for the fish in the Babolrud River and equaled 2180 and 2078 eggs on average respectively. The absolute fecundity of the loach from Dgał Wielki Lake was low and ranged from 175 to 452 eggs, as only the oocytes larger than $1 \mathrm{~mm}$ were counted (Boron and Danilkiewicz 2000). The number of oocytes obtained this way referred probably only to the first batch. Only the largest mature eggs were counted

Table 2

Absolute $\left(F_{a}\right)$ and relative $\left(F_{r}\right)$ fecundity in particular ranges of body length (SL), body weight $\left(W_{b}\right)$, and age of Cobitis sp. females from the Babolrud River

\begin{tabular}{|c|c|c|c|c|c|c|}
\hline \multirow{2}{*}{\multicolumn{2}{|c|}{ Parameter }} & \multirow{2}{*}{$n$} & \multicolumn{2}{|c|}{$F_{a}$} & \multicolumn{2}{|c|}{$F_{r}$} \\
\hline & & & Range & Mean \pm SD & Range & Mean \pm SD \\
\hline \multirow{3}{*}{$\mathrm{SL}[\mathrm{mm}]$} & $50.1-60$ & 11 & 734-1637 & $1467 \pm 418$ & $384-903$ & $617 \pm 225$ \\
\hline & $60.1-70$ & 14 & $918-2506$ & $2049 \pm 735$ & $347-945$ & $693 \pm 241$ \\
\hline & $\geq 70.1$ & 5 & $1962-3562$ & $2651 \pm 642$ & $415-877$ & $532 \pm 173$ \\
\hline \multirow{3}{*}{$W_{b}[\mathrm{~g}]$} & $2.1-3$ & 10 & 734-1933 & $1780 \pm 507$ & $384-830$ & $645 \pm 230$ \\
\hline & $3.1-4$ & 13 & $771-2940$ & $2157 \pm 793$ & $347-945$ & $583 \pm 209$ \\
\hline & $\geq 4.1$ & 7 & 1908-3562 & $2733 \pm 722$ & $556-784$ & $624 \pm 146$ \\
\hline \multirow{3}{*}{ Age } & $3+$ & 18 & $859-2125$ & $1529 \pm 641$ & $384-758$ & $595 \pm 172$ \\
\hline & $4+$ & 10 & 734-3194 & $2168 \pm 803$ & $347-945$ & $612 \pm 196$ \\
\hline & $5+$ & 2 & $2358-3562$ & $2960 \pm 851$ & $387-584$ & $485 \pm 140$ \\
\hline
\end{tabular}

$n=$ number of specimens; $\mathrm{SD}=$ standard deviation.

Correlation coefficients $r$ and regression equations for the relation between absolute fecundity $\left(F_{a}\right)$

Table 3 and: body length (TL), body weight $\left(W_{b}\right)$, weight of ovary $\left(W_{g}\right)$, and age

\begin{tabular}{|c|c|c|c|c|c|}
\hline Relation & $n$ & Linear regression & $r^{2}$ & F-value & P-value \\
\hline$F_{a}-\mathrm{TL}$ & 30 & $y=44.313 x-1022.2$ & 0.5613 & 1.689 & 0.440 \\
\hline$F_{a}-W_{b}$ & 30 & $y=483.79 x+389.57$ & 0.6762 & 4.315 & 0.045 \\
\hline$F_{a}-W g$ & 30 & $y=1287.2 x+967.61$ & 0.3034 & 24.385 & 0.022 \\
\hline$F_{a}-$ Age & 30 & $y=655.84 x-437.33$ & 0.2945 & 1.625 & 0.452 \\
\hline
\end{tabular}


in order to estimate the fecundity of the loach in the northern Italy (Marconato and Rasotto 1989). In this case, the number of eggs equalled 1012. According to LobónCerviá and Zabala (1984), the fecundity of the largest female C. paludicola amounted to 1400 eggs, whereas according to Bohlen (1998) the fecundity of the females of this species was much higher and ranged from 2905 to 4258 eggs (3618 on average). Statistically significant relations were found between the absolute fecundity and body weight and gonad weight in Cobitis sp. population from the Babolrud. The absolute fecundity of the fish from the Zegrzyński Reservoir ranged from 112 to 1520 eggs and was positively correlated with the body size, length, and the age of the females (Boron and Pimpicka 2000) and the relative fecundity ranged from 28 to 204 eggs per $1 \mathrm{~g}$ of the body weight, 108 on average. The relative fecundity in a related species of C. elongatoides ranged from 35 to 105 eggs (Erös 2000). The relative fecundity in the loach from the Babolrud River was higher and equalled 347 to 945 with a mean of 590 eggs per $1 \mathrm{~g}$ of a female body weight. According to present study, the relative fecundity in the loach from Klawój Lake amounted to 629 eggs (Juchno and Boroń 2006).

\section{ACKNOWLEDGEMENTS}

The authors are grateful to Cevher Ozeran, Ali Gholamifard and Fatih Mangit for their comments in this manuscript, Nihat Senol and Asta Aleksandraviciute for revision of the English and Hamid Ghasemnejad for his help in fish collections.

\section{REFERENCES}

'Abdolī A. [Abdoli A.], Nāderī M. [Naderi M.] 2009. Tanavvo'-e zīstī-yi māhīān-e howze-yi jonūbī-yi darya-yi khazar [The biodiversity of fishes of the southern basin of the Caspian Sea.] Abzian Scientific Publication, Tehran. [In Persian.]

Bagenal T.B. 1967. A short review of fish fecundity. Pp. 89-111. In: S.D. Gerking (ed.) The biological basis of freshwater fish production. Proceedings of IBP Symposium, Oxford.

Banarescu P., Nalbant T. 1966. The 3rd Danish expedition to central Asia. Zoological Results 34. Cobitidae (Pisces) from Afghanistan and Iran. Videnskabelige Meddelelser fra Dansk naturhistorisk Forening 129: 149-186.

Bianco P.G., Nalbant T. 1980. Redescription of Cobitis linea, with some remarks on the subgenus Bicanestrinia (Cypriniformes: Cobitidae). Copeia 1980 (4): 903-906. DOI: $10.2307 / 1444481$.

Bohlen J. 1998. Differences in clutch size, egg size and larval pigmentation between Cobitis taenia and C. bilineata (Cobitidae). Italian Journal of Zoology 65 (suppl. 1): 219-221. DOI: 10.1080/11250009809386817.

Boroń A., Danilkiewicz Z. 2000. Koza Cobitis taenia Linnaeus, 1758. [The spined loach Cobitis taenia Linnaeus, 1758.] Pp. 339-343. In: Brylinska M. (ed.) Ryby słodkowodne Polski. [The freshwater fishes of Poland.] PWN, Warszawa. [In Polish.]
Boroń A., Pimpicka E. 2000. Fecundity of spined loach, Cobitis taenia from the Zegrzyński Reservoir, Poland (Osteichthyes, Cobitidae). Folia Zoologica 49 (suppl. 1): $135-140$.

Canestrini G. 1871. Über das Männchen von Cobitis taenia Lin. Zeitschrift für wissenschaftliche Zoologie, Leipzig 21: 538-539.

Coad B.W. 2008. Freshwater fishes of Iran. http://www.briancoad.com (accessed on 17 May 2010).

Ekmekçi G., Erk'akan F. 2003. Preliminary data on growth and reproduction of Cobitis cimplicispina from Turkey. Folia Biologica 51 (suppl.): 183-186.

Erös T. 2000. Population biology of Cobitis elongatoides in a lowland stream of the Middle Danube (Hungary). Folia Zoologica 49 (suppl. 1): 151-157.

Halačka K., Lusková V., Lusk S. 2000. Fecundity of Cobitis elongatoides in the Nová Říše Reservoir. Folia Zoologica 49 (suppl. 1): 141-150.

Juchno D., Boroń A. 2006. Age, reproduction and fecundity of the spined loach Cobitis taenia L. (Pisces, Cobitidae) from Lake Klawój (Poland). Reproductive Biology 6 (2): 133-148.

Kostrzewa J., Przybylski M., Marszal L., Valladolid M. 2003. Growth and reproductive biology of loaches Cobitis sp. in Lake Lucień, Poland. Folia Biologica 51 (suppl.): 179-182.

Kottelat M., Freyhof J. 2007. Handbook of European freshwater fishes. Kottelat and Freyhof, Cornol, Switzerland and Berlin, Germany.

Lobón-Cerviá J., Zabala A. 1984. Observations on the reproduction of Cobitis paludicola De Buen, 1930 in the Jarama River. Cybium 8 (3): 63-68.

Marconato A., Rasotto M.B. 1989. The biology of a population of spined loach, Cobitis taenia L. Italian Journal of Zoology 56 (1): 73-80. DOI: 10.1080/11250008909355624.

Nikolsky G.V. 1963. The ecology of fishes. Academic Press, London.

Perdices A., Doadrio I. 1997. Phylogenetic relationships and classification of the genera Cobitis and Sabanejewia (Cobitidae) based on allozyme data. P. 71. In: Book of Abstracts; Ninth International Congress of European Ichthyologists (CEI9) "Fish Biodiversity". Napoli-Trieste, Italy.

Rinchard J., Kestemont P. 1996. Comparative study of reproductive biology in single- and multiple-spawner cyprinid fish. I. Morphological and histological features. Journal of Fish Biology 49 (5): 883-894. DOI: 10.1111/j.1095-8649.1996.tb00087.x.

Robotham P.W.J. 1981. Age, growth and reproduction of a population of spined loach, Cobitis taenia (L.). Hydrobiologia 85 (2): 129-136. DOI: 10.1007/BF00006622.

Wootton R.J. 1979. Energy costs of egg production and environmental determinants of fecundity in teleost fishes. Symposia of the Zoological Society of London 44: 133-159.

Wootton R.J. 1998. Ecology of teleost fishes. 2nd edn. Kluwer, Dordrecht.

Received: 22 October 2010 Accepted: 23 April 2011 Published electronically: 30 June 2011 